\title{
酸化多孔質シリコンを用いた マイクロブリッジの製作
}

$\begin{array}{lllll}\text { 非会員 } & \text { 渡 辺 一 } & \text { 仁 } & \text { (東海大短大) } \\ \text { 非会員 崔 } & \text { 一 } & \text { 煐 } & \text { (東海大短大) } \\ \text { 正 員 佐 藤 洋 一 } & \text { (東海大短大) } \\ \text { 正員 飯 } \text { 由 昌 盛 (東 海 大) }\end{array}$

\section{Fabrication of Microbridges Using Oxidized Porous Silicon}

Kazuhito Watanabe, Non-member, Il Yong Choe, Non-member, Yoichi Satoh, Member (Tokai University. Jr. College.), Masamori Iida, Member (Tokai University)

A new fabrication process of micromachines using oxidized porous silicon film has been developed. The porous silicon film with thickness of several micrometers was made from p-type silicon by anodization in $46 \% \mathrm{HF}$ solution and at a constant current density of $30 \mathrm{~mA} / \mathrm{cm}^{2}$. The porous silicon was thermally oxidized at $1,100^{\circ} \mathrm{C}$ for $30 \mathrm{~min}$. in dry $\mathrm{O}_{2}$ gas. Two types of microbridges were fabricated by using oxidized porous silicon as a sacrificial layer. It is shown that thick oxide layer can be selectively formed by using the porous silicon.

キーワード：多孔質シリコン, マイクロブリッジ，犠牲層, 選択酸化

\section{1.はじめに}

フッ化水素酸水溶液 (HF) 中でシリコンを陽極化 成処理すると，バイアス条件と HF 濃度によってシ リコン表面がエッチングもしくは多孔質化されること は古くから知られている(1)。近年, この陽極化成法を 用いたセンサや発光素子の開発が活発に行われ，シリ コンデバイスの応用範围を広げることから注目を浴び ている(2)。

シリコン・マイクロマシーニングにおいては, 陽極 化成法を用いて不純物濃度の違いによる選択的なエッ チング技術が開発され，いくつかのマイクロストラク チュアが試作されている(3)。

陽極化成による多孔質層の成長速度は速く, 数 $\mu \mathrm{m}$ の厚い層が比較的容易に形成できる。多孔質化したシ リコンは，酸素雾囲気中で熱処理することによって酸 化物に変化するので，厚い酸化膜が得られる（以下， この酸化膜を酸化多孔質膜という)。この性質を利用 して,これまでにICの絶縁分離層に応用した研究 p(4)(5)，酸化多孔質膜をマイクロマシーニングに応用 した例も紹介されている(6)。本論文では, 酸化多孔質 層の形成条件を明らかにし, それをマイクロマシーニ ングの㬢牲層に応用したマイクロブリッジの新しい製 作法について述べる。

\section{2. 酸化多孔質シリコン膜の特徵}

マイクロマシーニングの特徵的な技術の一つに犠牲 層の形成とエッチングがある。㩘牲層に要求される条 件は数 $\mu \mathrm{m} の$ 厚い膜であり，かつ，ほかの膜に影響を与 えずに容易にエッチングできることである。この条件 を満たすものとして，CVDにより形成された酸化膜 やリンガラスがよく使われている(7)。これらの酸化膜 は基板表面より上部に形成される。熱酸化膜では, 数 $\mu \mathrm{m}$ の膜は形成しにくく，また表面より $55 \%$ が上部 に, 残りの $45 \%$ は下部, すなわち深さ方向に形成さ れる。

酸化多孔質膜は表面より下部方向だけに数 $\mu \mathrm{m}$ から 数十 $\mu \mathrm{m}$ の愿い層を形成てき，伀導型（pまたはn 
型）によって選択的な多孔質化もできる特徵を有して いる。また, 酸化多孔質層の上にほかの膜を堆積して も表面との段差なく形成することができるので，これ までの犠牲層とは違った応用が可能である。

\section{3. 酸化多孔質シリコン膜の形成}

図 1 に陽極化成法を示す。HF 溶液中にシリコンウ エーハと白金を間隔 $4 \mathrm{~cm}$ で対向するようにビーカ中 にセットし，ピーカを超音波装置の中に置く。化学反 応が起きている間シリコンウェー八表面に気泡が生 じ，それが表面に付着するとその部分の反応が止まっ てしまうため，超音波で気泡の付着を防いでいる。ま た，図1のようにウェー八は表面だけで反応が促進さ れるように, 電流供給端子の領域と表面以外はエレク トロンワックスで保護する。電流は裏面から表面に向 って流れるようにしている。

シリコンには $\mathrm{p}$ 型, $\left(\begin{array}{lll}1 & 0 & 0\end{array}\right), 2 \sim 6 \Omega \cdot \mathrm{cm}$ の鏡面仕 上げされたウェー八を用いて, 裏面にボロンの熱拡散 を行っている。裏面の平均比抵抗は $0.007 \Omega \cdot \mathrm{cm}$ にな っている。HFには $5,20,30,46 \%$ の溶液を用い た。

図 2 に多孔質化処理時間に対する多孔質層の厚みを 示す。ここで, 電流密度 $J=30 \mathrm{~mA} / \mathrm{cm}^{2}$ 一定にし,

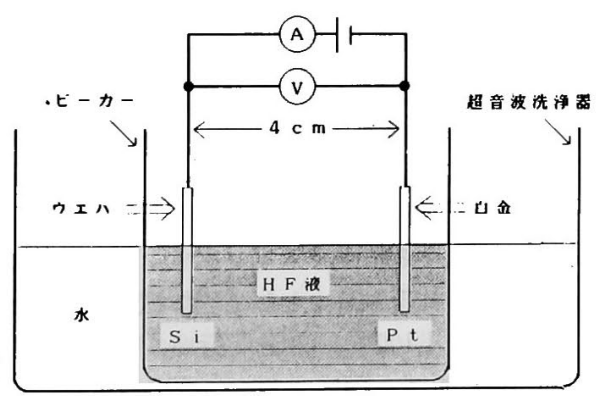

(a)

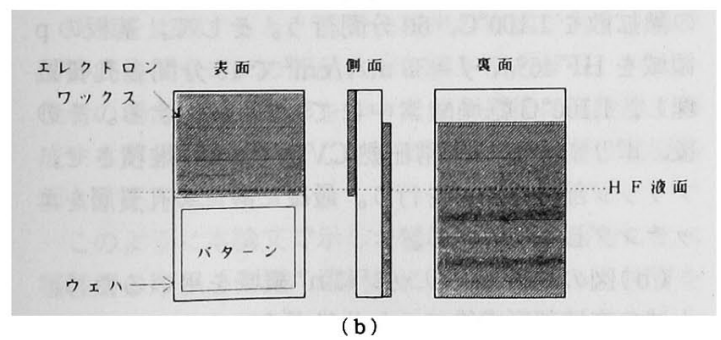

図 1 陽極化成法 ( a ) とウェー八の保護 ( b )

Fig. 1. Experimental setup (a) and wafer protection ( $b$ ) fo anodization.
$\mathrm{HF}$ 濃度は 46\%である。また，多孔質化には正孔の 存在が寄与するので, 電子一正孔対を発生させる光の 影響を一定とするために照明は室内光のみとした。電

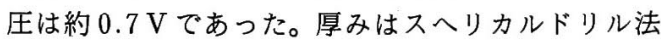
で測定した。多孔質化のレートは約 $0.4 \mu \mathrm{m} / \mathrm{min}$ であ る。短時間に数 $\mu \mathrm{m}$ の多孔質層が形成されることがわ かる。HF 濃度が $30 \%$ 以下になると電解研磨の現象 が現れ表面に激しい凹凸が発生し, 剥離する場合もあ った。電流の増加に対してはウェーハから発生する気 泡が増大し, 面内で不均一が生じ剥離現象も現れる。 また, 低電流ては多孔質化レートが低くなるので現段 階では図 2 の条件が最適である。

図 3 に多孔質処理後の代表的な基板断面の SEM 写 真を示す。無数の細孔がランダムに生じていることが わかる。また, 孔径は数十 $\mathrm{nm}$ でありメソ多孔質構造 (孔径 2〜 $50 \mathrm{~nm}$ ) になっている( ${ }^{(8)}$ 。

多孔質化されたウェー八は $1,100^{\circ} \mathrm{C}$, 乾燥酸素中に て 30 分以上の熱処理によって酸化される。スヘリカ

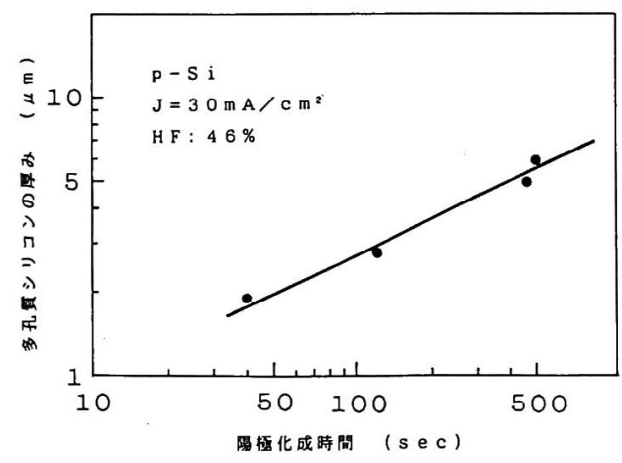

図 2 陽極化成時間に対する多孔質シリコン の厚み

Fig. 2. Thickness of porous silicon versus anodization time.

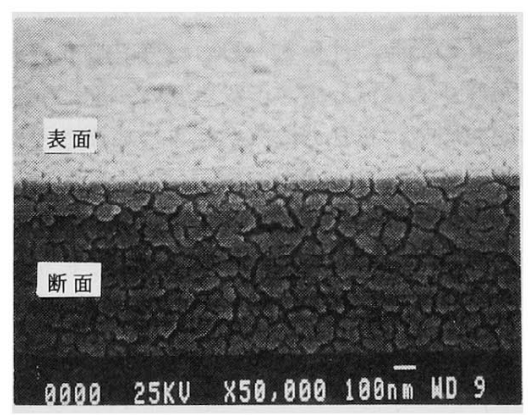

図 3 多孔質シリコンの SEM 写真

Fig. 3. SEM micrograph of porous silicon. 
(a) 多孔質処理 および酸化後

（b）エッチング後

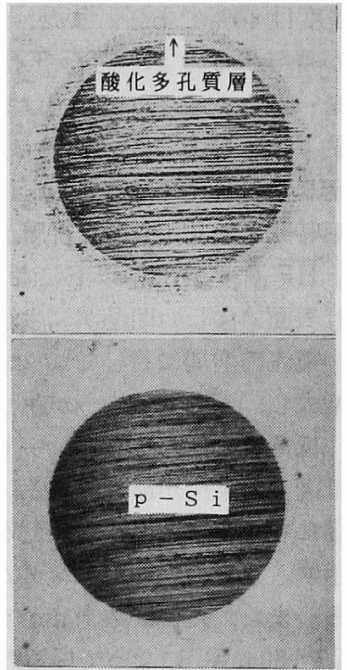

図 4 スヘリカルドリルで研磨した後の ウェー八の顕微鏡写真

Fig. 4. Microphotograph of wafer after polishing by spherical drill.

ルドリルで, 酸化後に研磨した面と, その酸化膜をエ ッチングで除去した面の顕微鏡写真を図 4 に示す。 (b) 図で二重円の外円部分が消滅したことは酸化層が 除去されたことを示している。エッチングはバッファ ード HFで 50 秒行い, 疎水性も確認された。酸化し た多孔質層はHF によるエッチングで簡単に除去さ れ，他の報告からも酸化層であるといえる(4)(5)。

上述と同様な実験を $\mathrm{n}$ 型基板についても行った。 実験結果によると, ごく薄く表面に多孔質層が形成さ れているようであるが，その厚みは測定不可能なほど 薄かった。

陽極化成の反応過程にはシリコン基板内の正孔が関 与するので $\mathrm{n}$ 型基板を多孔質化する場合, 何らかの 方法で正孔の注入を行わなければならない(1)。このこ とは，正孔の発生や注入がなければ多孔質化されない ことを意味する。従って, $\mathrm{p}$ 型基板の一部に $\mathrm{n}$ 領域を 形成した試料で，正孔の注入が起きないような条件で 多孔質処理を行うと $\mathrm{n}$ 領域は多孔質化されないこと になる。このことより, 選択的な酸化多孔質膜の形成 も可能である。

\section{4. 酸化多孔質シリコン膜を用いたマイクロ プリッジの製作}

酸化多孔質シリコン膜の犠牲層への応用としてマイ クロブリッジの試作を行った。ブリッジ部分をポリシ
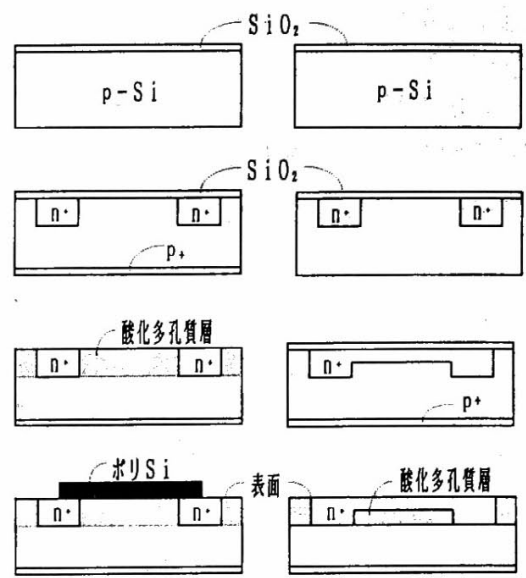

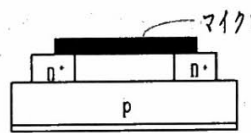

(a) ポリシリコンマイクロ ブリッジ

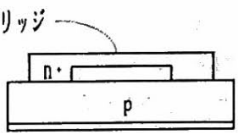

(b) $\mathrm{n}^{+}$シリコンマイクロ プリッジ

図 5 マイクロブリッジの製作工程

Fig. 5. Process sequence of microbridges.

リコンで形成した場合（ポリシリコンマイクロブリッ ジ）と選択的な酸化多孔質処理法でシリコン基板自体 を加工して形成した場合（ $\mathrm{n}^{+}$シリコンマイクロブリ ッジ) の 2 通りの製作方法について検討した。

図 5 に 2 通りの製作プロセスを断面構造で示す。両 者とも基板には第 3 章の実験と同じ $\mathrm{p}$ 型基板を用い た。

まず, 共通の工程として, $1,100^{\circ} \mathrm{C}$, 乾燥酸素中に て 160 分熱酸化する。フォトリソグラフィ工程で酸化 膜を加工し，それをマスクとして固体拡散源を用いて リンの熱拡散を $1,100^{\circ} \mathrm{C}, 60$ 分間行い，ブリッジの支 持部となる $\mathrm{n}^{+}$領域を形成する。（a 図の場合につい て説明する。支持部の拡散を終えた後, 裹面にボロン の熱拡散を $1,100^{\circ} \mathrm{C}, 60$ 分間行う。そして, 基板の $\mathrm{p}$ 領域を $\mathrm{HF} 46 \%, J=30 \mathrm{~mA} / \mathrm{cm}^{2}$ で 15 分間多孔質処 理し, $1,100^{\circ} \mathrm{C}$ 乾燥酸素中にて 30 分酸化する。その 後, ポリシリコンを常圧熱 CVDで $2 \mu \mathrm{m}$ 堆積させ, ブリッジ部分の加工を行う。最後に酸化多孔質層を工 ッチングして完成する。

（b）図の場合はブリッジに $\mathrm{n}^{+}$領域を用いるため, 上述の支持部形成後フォトリソグラフィによる酸化膜 加工後に再度リン拡散を行う。そして, 裏面にボロン 拡散を行った後, 表面の $\mathrm{p}$ 領域を選択的に酸化多孔 質化し，エッチングを行い完成する。 


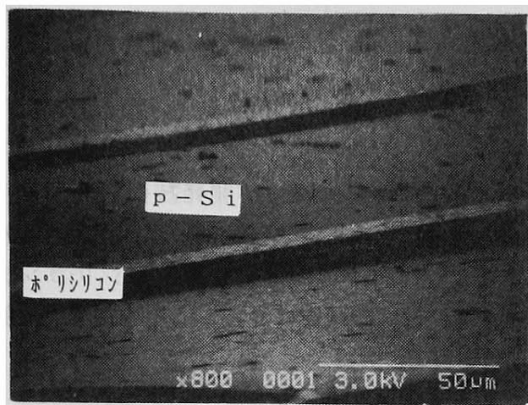

図 6 ポリシリコンマイクロブリッジの SEM 写真 Fig. 6. SEM micrograph of polysilicon microbridge.

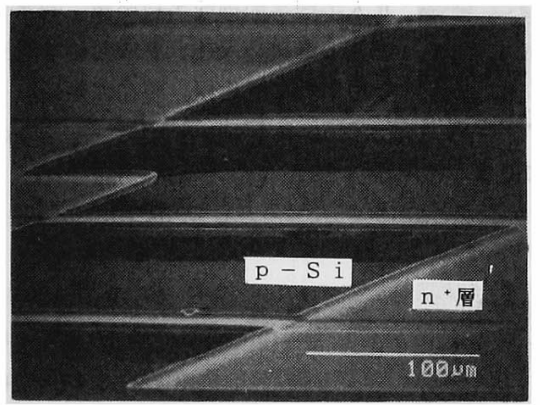

図 7 選択的な多孔質層形成によって作られた $\mathrm{n}^{+}$シリコンマイクロブリッジの SEM 写真

Fig. 7. SEM micrograph of $\mathrm{n}^{+}$silicon microbridge made by the selective formation of porous silicon.

ポリシリコンマイクロブリッジの SEM 写真を図 6 に示す。基板とポリシリコン間に明らかな空間が生じ ていることがわかる。図 7 は $\mathrm{n}^{+}$シリコンマイクロブ リッジの SEM 写真である。選択的な酸化多孔質層の 形成によって加工が行われていることがわかる。

両者を比較すると, 前者は従来の方式であり, 犠牲 層形成後にマシンの部品になる膜を積上げる。一方, 後者の場合, 部品の形を作っておきき最後に犠牲層を形 成する方式である。そして，両者とも犠牲層は基板表 面より下方に位置する。

このように本論文で示した犠牲層は他の報告に比べ 犠牲層の厚み, 位置, 選択性において異なった性質を もっていることがわかる。

選択的な酸化多孔質層形成法で $\mathrm{n}^{+}$シリコンマイク ロカンチレバを製作した。多孔質化処理の途中の SEM 写真を図 8 に示す。ブリッジの下部にはまだ $\mathrm{p}$

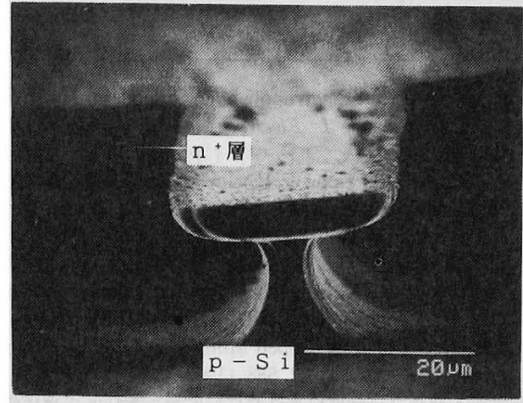

図 8 選択的な多孔質層形成によって作られた $\mathrm{n}^{+}$シリコンマイクロカンチレバの SEM 写真 Fig. 8. SEM micrograph of $\mathrm{n}^{+}$silicon microcantilever made by the selective formation of porous silicon.

基板の非多孔質層が残っている状態であり，ブリッジ の形状は $\mathrm{n}^{+}$層で形成されたものであることがみられ る。多孔質化は陽極化成時の電流方向に進行し, 横方 向には深さに対して $0.7 \sim 1$ の比率で広がるといわれ ている(5)。この場合も写真からおおよその比率を見積 ると.8〜.9である。また, 図 8 は pn 接合の形状とほ ほ一致することから電流は, $\mathrm{pn}$ 接合面に沿って, $\mathrm{n}^{+}$ 層を避けるように流れていることが予測できる。この 結果は, 犠牲層の深さを決定するときの目安になるも のといえる。

\section{5. まとめ}

本研究では, シリコンを多孔質化することによって 厚い酸化膜が選択的に形成できることを示した。ま た，この酸化膜がマイクロマシーニングの犠牲層に応 用できることを明らかにした。

しかし，酸化膜エッチング後シリコン基板に凹凸が 発生したり，ウェー八内での多孔質層の厚みに不均一 が生じた。この現象は, 陽極化成時の電流がウェー八 内で一様に流れなかったためで, 改善法としてはエピ

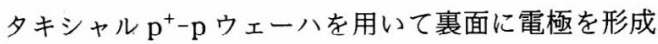
することが挙げられる。更に, HF 溶液の循環装置を 導入し，ウェー八面内で溶液の状態を一定にすること などである。これらは今後の課題として残された。ま た，ブリッジを構成しているポリシリコンと単結晶シ リコンでの応力, 強度の違いなどについても今後の課 題である。

最後に, 実験に協力いただいた卒研生 伊藤克彦, 歸山文國の両氏に感謝する。

(平成 4 年 3 月 25 日受付) 


\section{文 献}

(1) D. R. Turner: "Electropolishing Silicon in Hydrofluoric Acid Solutions", J. Electrochem. Soc., 105, No. 7, 402 (1958)

(2) A. Richter, P. Steiner, F. Kozlowski \& W. Lang: "Current -Induced Light Emission from a Porous Silicon Device", IEEE Electron Device Lett., 12, No. 12, 691 (1991)

(3) C. J. M. Eijkel, J. Branebjerg, M. Elwenspoke \& F. C. M. Vandepol: "A New Technology for Micromachining of Silicon: Dopanat Selective HF Anodic Etching for the Realization of Low-Doped Monocrystalline Silicon Structures", ibid., 11, No. 12, 588 (1990)

（4）渡辺・酒井：「高抵抗多孔質けい秦膜の製作と半導体部品一 の応用」, 電電公社研究実用化報告, 49, No.11, 2101（昭 45)

（5）佐藤：「多孔質絶緑物の集積回路への応用」, 沖電気研究開 発, 42, No.1, 199 (昭 50)

(6) T. Yoshida, T. Kudo \& K. Ikeda: "Photo-Induced Preferential Anodization for Fabrication of Monocrystalline Micromechanical Structures", Micro Elctro Mechanical Systems ' 92, p. 56

（7）例えば,Y-C. Tai \& R.S. Muller: "IC-Processed Electrostatic Synchronous Micromotors, Sensors \& Actuators, 20, 49 (1989)

(8) L. T. Canham: "Silicon Quantum Wire Array Fabrication by Electrochemical and Chemical Dissolution of Wafers", Appl. Phys. Lett., 57, No. 10, 1046 (1990)

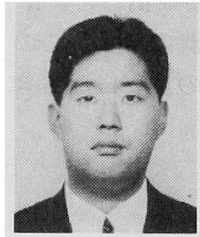

事。

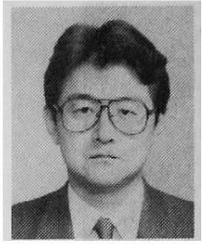

崔 一 愥（非会員）

1955 年 10 月 11 日生。 59 年 3 月東海 大学大学院工学研究科博士課程修了。同 年 7 月同大学開発技術研究所助手, 62 年 4 月同大学短期大学部講師, 現在に至 る。工学博士。深い不純物準位を有するシリコンデバイ ス, マイクロマシンの研究に従事。応用物理学会; 電子情 報通信学会, IEEE 会員。

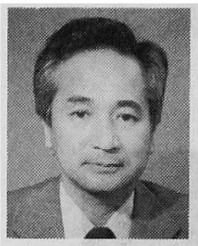

佐 藤 洋 一 (正員)

昭和 10 年 10 月 24 日生。 35 年 3 月東 北大学理学部物理学科卒業。同年 4 月沖 電気工業(株) 入社。平成元年 4 月東海大 学短期大学部教授, 現在に至る。トラン ジスタ, 半導体集積回路, シリコンマイクロマシンの研究 開発に従事。応用科学学会, 日本 AEM 学会会員。

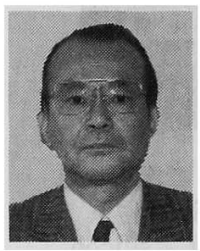

飯 田 昌 盛 (正員)

昭和 14 年 4. 月 8 日生。 44 年 10 月早 稲田大学大学院理工学研究科博士課程修 了。 41 年 4 月東海大学工学部講師を経 て, 50 年 4 月同教授, 現在に至る。工学 博士。深い不純物準位を有する半導体, アモルファス半導 体, ダイヤモンド半導体のデバイス化に関する研究に従 事。応用物理学会, 物理学会会員。 